\title{
Relationship Between the Levels of Non-structural Carbohydrates, Digging Date, Nursery-growing Environment, and Chilling in Strawberry Transplants in a Subtropical Environment
}

\author{
Christopher M. Menzel ${ }^{1}$ and Lindsay Smith \\ Department of Employment, Economic Development and Innovation, P.O. \\ Box 5083, SCMC, Nambour, Queensland 4560, Australia
}

Additional index words. Fragaria $\times$ ananassa, bare-rooted, climate, propagation, soluble sugars, starch

\begin{abstract}
Experiments were conducted to study the effect of time of digging and nurserygrowing environment on the levels of non-structural carbohydrates in 'Festival' strawberry transplants (Fragaria $\times$ ananassa) over 2 years in southeastern Queensland, Australia. We were interested in determining whether there was a strong relationship between the potential productivity of this material and reserves in the plants. First, barerooted plants were obtained from Stanthorpe in southern Queensland from early March to mid-April/late April. Second, bare-rooted plants were sourced from Stanthorpe (a warm-growing area) or from Toolangi in Victoria (a cool-growing area). In Year 1 of the experiments, the nursery material from the different treatments was grown at Nambour in southeastern Queensland and fruit yield determined. The total weight of nonstructural carbohydrates/plant increased as digging was delayed and was higher in the plants from Stanthorpe than the plants from Toolangi. Plants dug on 17 Mar. in Year 1 had higher weights of non-structural carbohydrates [292 mg/plant dry weight (DW)] than plants dug on 3 Mar. (224 mg/plant) and higher early yield to the end of June or to the end of July and higher total yield to mid-October adjusted by the length of the growing season for the different treatments. Plants dug on 1 Apr. (408 mg/plant) or on 13 Apr. (445 mg/plant) had higher reserves than the plants dug on 17 Mar. but lower yields. Only the differences in yields between the plants dug on 3 Mar. and 17 Mar. reflected the differences in carbohydrates. The stock from Stanthorpe had greater reserves $(408 \mathrm{mg} / \mathrm{plant})$ than the stock from Toolangi $(306 \mathrm{mg} / \mathrm{plant})$ but similar yields in Year 1 possibly because of poorer flowering in the nursery plants. It was concluded that carbohydrate reserves in transplants only partially reflect their productivity in this environment.
\end{abstract}

Strawberry growers in southeastern Queensland produce berries from May to October in a subtropical climate. Total cultivation is $\approx 600$ ha, worth U.S. $\$ 147$ million (Menzel and Toldi, 2010). The industry in southeastern Queensland shares many similarities with the industry in Florida. There are common cultivars, production techniques, and pests and diseases in these two growing areas (Peres et al., 2009; Vock, 1997). Total cultivation in Florida is $\approx 4000$ ha, worth $\approx$ U.S. $\$ 330$ million (Santos et al., 2009; Whitaker et al., 2011).

Received for publication 9 Jan. 2012. Accepted for publication 28 Feb. 2012

We thank Horticulture Australia Limited (HAL), Strawberries Australia, the Queensland Strawberry Growers' Association, Florida Strawberry Growers' Association, Sweets Strawberry Runners, Red Jewel Nursery, and Toolangi Certified Strawberry Runner Growers' Co-operative for supporting this research. ${ }^{1}$ To whom reprint requests should be addressed; e-mail chris.menzel@deedi.qld.gov.au.
Producers in southeastern Queensland obtain new bare-rooted transplants from nurseries situated at Stanthorpe in southern Queensland or at Toolangi in Victoria. Conditions in the southern growing area are $\approx 2$ to $3{ }^{\circ} \mathrm{C}$ cooler during nursery plant development compared with those in the northern growing area. There are also differences in photoperiod, which can impact on growth, flowering, and fruit production in short-day strawberry plants (Stewart and Folta, 2010). Low temperatures can increase the distribution of plant DW to the roots, which are important storage tissues (Bringhurst et al., 1960; Wang and Camp, 2000). Short days can induce flower production in the nursery plants before they are harvested (Durner et al., 1984).

Previous research showed that the optimum time for the planting of 'Festival' in southeastern Queensland is mid-March with lower productivity from earlier or later plantings (Menzel and Smith, 2011). It was postulated that the poorer performance of the material planted in early March compared with the performance of plants planted in mid-March was related to the small size of the plants. The lower yield of the plants planted after mid-March was related to the shorter growing season. This work also demonstrated that nursery material from Queensland and Victoria had similar productivity when grown in southeastern Queensland.

Non-structural carbohydrates are used by plants for growth and metabolism and generally include substances such as starch (storage sugar) and soluble sugars, which do not form part of the cell structures such as the cell wall (Da Silveira et al., 1978). These carbohydrates are then available for cell metabolism, whereas carbohydrates in the cell wall such as cellulose are generally not available for respiration, etc. Da Silveira et al. (1978) indicated that "The energy readily available to a plant is determined by total non-structural carbohydrate (TNC) analyses." Soluble sugars are immediately available for metabolism, whereas starch must be broken down into individual units of glucose before it can be metabolized.

Several studies have examined the relationship between nursery plant quality and the concentration of non-structural carbohydrates in strawberry transplants (Bringhurst et al., 1960; Hicklenton and Reekie, 2000; Kirschbaum et al., 1998; Lieten et al., 1995; López et al., 2002; Palha et al., 2002; Ruan et al., 2009; Schupp and Hennion, 1997).

Palha et al. (2002) investigated the relationship between fruit production and the concentration of non-structural carbohydrates in the roots of 'Chandler' and 'Douglas' transplants in Portugal over 2 years. The plants were dug in mid-October, early November or mid-November, and stored at $2{ }^{\circ} \mathrm{C}$ for 0,2 , or 4 weeks before being planted. The concentration of starch generally increased as harvesting was delayed and decreased the longer the plants were stored. In contrast, there were small or no significant changes in the concentration of soluble sugars. There was a strong correlation between early yield and the concentration of non-structural carbohydrates in the roots before planting $\left(R^{2}=\right.$ $0.73)$. The results of this experiment show the importance of reserves for the establishment and growth of strawberry transplants.

Most of the studies on carbohydrates in transplants relate to stock that was stored in a cold room before planting and grown in a temperate or Mediterranean environment. There have been only a few investigations that relate to plants that were planted as soon as they were dug and grown in a subtropical environment. Bare-rooted plants grown for producers in subtropical areas are generally supplied with the leaves intact, whereas barerooted plants grown for producers in temperate or Mediterranean areas are generally supplied with the leaves pruned.

Kirschbaum et al. (1998) measured the concentration of non-structural carbohydrates in plants of 'Sweet Charlie' grown in Canada (a cool site) or Florida (a warm site) and planted in Florida. The northern-grown plants had a slightly higher concentration of soluble 
sugars in the crown than the southern-grown plants (5.5 vs. $\left.4.3 \mathrm{mg} \cdot \mathrm{g}^{-1} \mathrm{DW}\right)$ and two to three times the concentration of soluble sugars (4.6 vs. $\left.1.5 \mathrm{mg} \cdot \mathrm{g}^{-1}\right)$ or starch (5.1 vs. $\left.2.1 \mathrm{mg} \cdot \mathrm{g}^{-1}\right)$ in the roots. There were no significant differences in the concentration of reserves stored in the leaves. These authors concluded that the better performance of northern-grown plants in Florida is likely to be related to a greater concentration of carbohydrates in the plants, especially in the roots. There could also be differences in flowering related to differences in daylength between the two growing areas (Stewart and Folta, 2010) and differences in the incidence of diseases (MacKenzie et al., 2009).

We report on the effect of time of digging and nursery-growing environment on the reserves of non-structural carbohydrates in bare-rooted plants of 'Festival' grown in southeastern Queensland over 2 years. First, the material was grown at Stanthorpe and harvested at various times from early March to late April. The samples were then transported to the laboratory at Nambour, and plant DW and the concentrations of soluble sugars and starch determined. In a separate experiment, plants were obtained from a nursery at Stanthorpe (a warm site) or from a nursery at Toolangi in Victoria (a cool site) for a similar analysis. In Year 1 of the experiments, the nursery material from the different treatments was grown at Nambour and fruit yield determined.

Our study differs from previous research in that the total amount of non-structural carbohydrates in the plants was determined, not just the concentration. Small changes in the concentration of reserves are likely to be important if they contribute to large changes in absolute weights of reserves. It is therefore important to measure the dry weight of the plants along with the concentration of reserves (Goldschmidt and Golomb, 1982; Menzel et al., 1995). We proposed that the total amount of reserves would increase as digging was delayed and that the stock from Toolangi would have greater reserves than the stock from Stanthorpe. We were particularly interested in determining if the poor performance of transplants planted in early March compared with that of transplants planted in mid-March (Menzel and Smith, 2011) was the result of low levels of carbohydrates in the nursery material.

\section{Materials and Methods}

Time of digging. In 2008, bare-rooted plants of the strawberry cultivar Festival, growing at Stanthorpe in southern Queensland (lat. $28.6^{\circ} \mathrm{S}$, long. $152.0^{\circ} \mathrm{E}$, elevation $872 \mathrm{~m}$ ), were dug on 3 Mar., 17 Mar., 1 Apr., or on 13 Apr. The mother plants from which these transplants were taken were planted in October the previous year and grown as a commercial nursery crop over summer on a fine sandy soil under standard horticultural practices (Vock, 1997). The amount of chilling below 7.2 and $10{ }^{\circ} \mathrm{C}$ accumulated by the transplants from 1 Jan. up to the time of digging was calculated for each of the harvesting dates.

The plants were transported overnight to Nambour; separated into leaves, crown, and roots; and dried in an oven at $60{ }^{\circ} \mathrm{C}$ for $3 \mathrm{~d}$ to determine plant dry weight. Samples from individual boxes containing 500 plants were used as replicates. The consignments were selected at random at the packhouse. The concentrations of non-structural carbohydrates (starch, sucrose, fructose, glucose, maltose, and sorbitol) in the leaves, crown, and roots were also determined (Macías-Rodríguez et al., 2002) on pooled samples from 15 or 30 plants for each replicate $(\mathrm{n}=$ four replicates per treatment). The analysis for starch was conducted using a Megazyme total starch assay kit using the alpha amylase/amyloglucosidase method (<http://www.megazyme.com $>$ ). The analysis for soluble sugar profile was conducted using high-performance liquid chromatography (HPLC). The sugars were extracted and analyzed by HPLC using the relevant reference standards. The weight of carbohydrates in the leaves, crown, and roots was calculated by multiplying plant dry weight by the concentration of carbohydrates in the different plant parts.

The concentration of non-structural carbohydrates in strawberry plants has been described in various terms, including starch (Bushway and Pritts, 2002; Pertuzé et al., 2006), soluble sugars (Ohi et al., 1995), or starch and soluble sugars (Gagnon et al., 1990; Kirschbaum et al., 1998; Lieten, 1997; Lieten et al., 1995). Sometimes several individual sugars are listed (Nishizawa, 1994; Nishizawa and Shishido, 1998; Nishizawa et al., 1997; Ruan et al., 2009). Finally, some authors present their data as "total nonstructural carbohydrates" where the values for sugars and starch are combined (Kirschbaum et al., 2010). Some investigators include values for a single plant part or part of the tissue (e.g., a core of the crown). There are also differences in analytical techniques with the values presented on a wet weight or DW basis.

The data on plant DW, DW distribution, weight of carbohydrates/plant, and the distribution of carbohydrates in the plant were analyzed by two-way analyses of variance (ANOVA; 2 years $\times$ four digging times), with no blocking, using Genstat (Version 11; VSN International, Hemel Hempstead, U.K.). The data on the concentration of non-structural carbohydrates in the plants were analyzed by two-way ANOVA ( 2 years $x$ four digging times) with separate analyses for the leaves, crown, and roots and with no blocking.

In the ANOVAs to examine the effect of time of digging on plant DW, plant DW distribution, weight of non-structural carbohydrates, and the distribution of non-structural carbohydrates, the effect of time of digging was much greater $(P<0.001)$ than the interaction between time of digging and year, which was not significant $(P>0.05)$ or less significant $(P$ values generally between 0.02 and 0.04$)$. Hence, the data on plant growth and carbohydrate levels have been presented as general means (effect of time of digging) pooled over the 2 years.

The relationship between the concentration of carbohydrates in the plants and the number of days in the nursery since 1 Jan. and the accumulation of chilling below 7.2 or $10{ }^{\circ} \mathrm{C}$ with the different times of digging was assessed by regression. The graphics software, SigmaPlot (Version 11; Systat, Chicago, IL), was used to analyze these data.

We also collected data on fruit yield from the different times of digging in 2008. Plants from the different treatments were planted at Nambour (lat. 26.6 $\mathrm{S}$, long. $152.9^{\circ} \mathrm{E}$, elevation $29 \mathrm{~m}$ ) 1 or $2 \mathrm{~d}$ after digging at Stanthorpe. The strawberry plants were grown as commercial crops as described by Menzel and Toldi (2010) and Vock (1997). The experiment was laid out in five randomized blocks with the fruit harvested each week from the same 20 plants in each plot $(n=100$ plants per treatment). Information was collected on early yield to the end of June or to the end of July and total yield to midOctober adjusted by the length of the growing season for the different treatments $(22$, 24,26 , and 28 weeks). These data were analyzed by one-way ANOVA (four digging dates).

A second experiment was conduced in 2010 with a similar set-up and data analyses as in 2008. The transplants were harvested on 7 Mar., 29 Mar., 11 Apr., or on 26 Apr. These times of digging were slightly later than in the first experiment. No yield data were collected in 2010.

Nursery-growing environment. Bare-rooted plants of 'Festival' were obtained from Stanthorpe and from Toolangi in Victoria (lat. $37.6^{\circ} \mathrm{S}$, long. $145.5^{\circ} \mathrm{E}$, elevation $620 \mathrm{~m}$ ) on 1 Apr. in 2008. Stanthorpe was considered a warm-growing area for nursery production, whereas Toolangi was considered a coolgrowing area.

Samples from individual boxes containing 500 plants were used as replicates. The plants from the nursery at Stanthorpe in this experiment were the same as the plants that were dug in early April in the previous experiment. The plants were separated into leaves, crown, and roots to determine plant DW and concentrations of non-structural carbohydrates as described previously. The chemical analyses were conducted on pooled samples from 15 plants for each replicate $(\mathrm{n}=$ four replicates per treatment). The data on plant DW, DW distribution, weight of carbohydrates/plant, and the distribution of carbohydrate in the plant were analyzed by two-way ANOVA ( 2 years $\times$ two sources), with no blocking. The data on the concentration of non-structural carbohydrates in the plants were analyzed by two-way ANOVA ( 2 years $x$ two sources) with separate analyses for the leaves, crown, and roots and with no blocking.

Data on fruit yield from the two nurserygrowing areas were collected in 2008. Plants from the different treatments were planted at Nambour 1 or $2 \mathrm{~d}$ after digging at Stanthorpe or Toolangi. The experiment was laid out in four randomized blocks with the fruit 
Table 1. The effect of time of digging on plant dry weight and distribution [within brackets] and on the weight and distribution [within brackets] of non-structural carbohydrates in 'Festival' strawberry plants grown at Stanthorpe in southern Queensland, Australia, in 2008 and 2010.

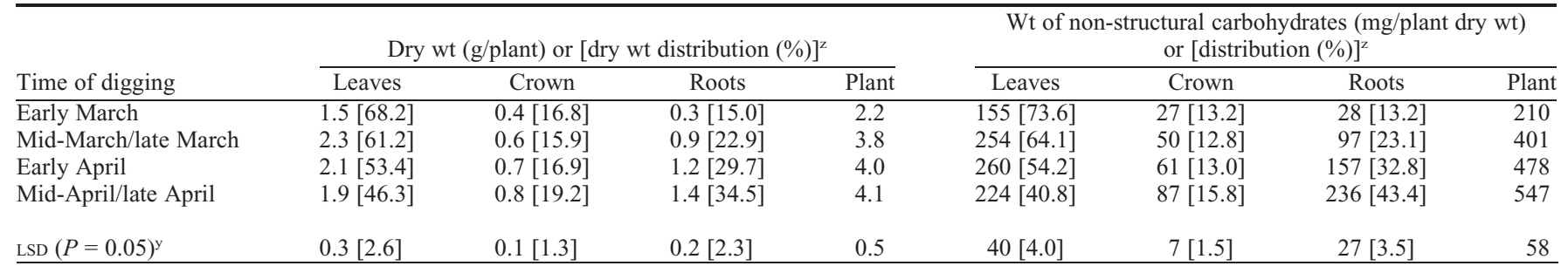

${ }^{\mathrm{z}}$ Data are the means of eight replicates per treatment pooled over 2 years; $1 \mathrm{~g}$ dry weight $=0.0353 \mathrm{oz}$. The transplants were dug on $3 \mathrm{Mar}$., $17 \mathrm{Mar}$., $1 \mathrm{Apr}$., or on 13 Apr. in 2008 and on 7 Mar., 29 Mar., 11 Apr., or on 26 Apr. in 2010.

${ }^{y}$ LSD is least significant difference for the means calculated from the analysis of variance.

harvested each week from the same 40 plants in each plot $(\mathrm{n}=160$ plants per treatment). The plants were grown in a separate experiment to those in the first experiment, which compared different digging dates. Information was collected on early yield to the end of June or to the end of July and total yield to mid-October. Total yield was not adjusted for the length of the growing season that was identical in the two treatments. These data were analyzed by one-way ANOVA (two sources).

A second experiment was conduced in 2010 with a similar set-up and data analyses as in 2008. The transplants were harvested on 11 Apr., slightly later than in 2008. No yield data were collected in 2010.

In the ANOVAs to examine the effect of source of nursery material on the performance of the plants, there was no significant $(P>0.05)$ interaction between source of nursery material and year on plant DW, plant DW distribution, weight of non-structural carbohydrates, and the distribution of nonstructural carbohydrates. Hence, the data on plant growth and levels of carbohydrates are presented as general means (effect of nurserygrowing environment) pooled over the 2 years.

\section{Results}

Time of digging. In 2008, the first two sets of plants accumulated little chilling below $10{ }^{\circ} \mathrm{C}(8$ or $17 \mathrm{~h})$ and no chilling below $7.2^{\circ} \mathrm{C}$. There was a steady increase in chilling below $10^{\circ} \mathrm{C}(57$ or $83 \mathrm{~h})$ and below $7.2^{\circ} \mathrm{C}$ (30 or $42 \mathrm{~h}$ ) over the next two harvests. Similarly, in 2010, there was a steady increase in the amount of chilling below $10^{\circ} \mathrm{C}$ because digging was delayed $(21,24,35$, or $85 \mathrm{~h})$ but little chilling below $7.2{ }^{\circ} \mathrm{C}(8,8,8$, or $18 \mathrm{~h}$ ).

Plant DW was higher in the last three harvests compared with the first harvest as a result of higher leaf weight and especially crown and root weight (Table 1). There was also a change in the distribution of plant weight with a decrease in the proportion of dry matter allocated to the leaves because harvesting was delayed and an increase in the proportion allocated to the roots (Table 1). Allocation to the crown varied little with the time of harvest.

The main non-structural carbohydrates measured in the strawberry plants were glucose [mean concentration of $4.0 \% \pm 0.1 \%$

Table 2. The effect of time of digging on the concentration of non-structural carbohydrates in 'Festival' strawberry plants grown at Stanthorpe in southern Queensland, Australia, in 2008 and 2010.

\begin{tabular}{|c|c|c|c|c|c|c|c|}
\hline \multirow[b]{2}{*}{ Time of digging } & \multicolumn{7}{|c|}{ Concn of non-structural carbohydrates $(\% \text { dry wt })^{z}$} \\
\hline & Glucose & Fructose & Sucrose & Maltose & Total sugars & Starch & $\begin{array}{c}\text { Total } \\
\text { carbohydrates }\end{array}$ \\
\hline & & & & & Leaves & & \\
\hline Early March & 4.1 & 2.9 & 2.1 & 0.1 & 9.3 & 1.0 & 10.3 \\
\hline Mid-March/late March & 4.1 & 3.2 & 2.5 & 0.2 & 10.1 & 1.3 & 11.4 \\
\hline Early April & 4.4 & 3.6 & 2.2 & 0.3 & 10.5 & 1.6 & 12.1 \\
\hline Mid-April/late April & 4.3 & 3.5 & 2.0 & 0.4 & 10.2 & 1.5 & 11.7 \\
\hline $\operatorname{LSD}(P=0.05)^{\mathrm{y}}$ & NS & 0.4 & 0.3 & 0.1 & NS & 0.1 & 1.2 \\
\hline & & & & & Crown & & \\
\hline Early March & 3.2 & 2.3 & 0.8 & 0.1 & 6.4 & 1.1 & 7.5 \\
\hline Mid-March/late March & 3.3 & 2.8 & 0.9 & 0.1 & 7.1 & 1.4 & 8.5 \\
\hline Early April & 3.3 & 2.8 & 0.7 & 0.3 & 7.2 & 1.9 & 9.0 \\
\hline Mid-April/late April & 3.8 & 3.4 & 0.9 & 0.6 & 8.8 & 2.2 & 11.0 \\
\hline $\operatorname{LSD}(P=0.05)$ & 0.3 & 0.2 & 0.1 & 0.1 & 0.5 & 0.2 & 0.6 \\
\hline & & & & & Roots & & \\
\hline Early March & 3.9 & 2.2 & 0.5 & 0.2 & 6.8 & 1.6 & 8.4 \\
\hline Mid-March/late March & 4.3 & 3.1 & 0.7 & 0.4 & 8.5 & 2.3 & 10.8 \\
\hline Early April & 4.5 & 3.4 & 0.6 & 0.9 & 9.5 & 3.6 & 13.1 \\
\hline Mid-April/late April & 4.3 & 4.3 & 1.0 & 1.1 & 10.8 & 6.0 & 16.8 \\
\hline $\operatorname{LSD}(P=0.05)$ & NS & 0.5 & 0.3 & 0.1 & 1.2 & 0.4 & 1.6 \\
\hline
\end{tabular}

${ }^{\mathrm{z}}$ Data are the means of eight replicates per treatment pooled over 2 years. The values for total sugars include values for the concentration of sorbitol; $1 \mathrm{~g}$ dry weight $=0.0353 \mathrm{oz}$. The transplants were dug on 3 Mar., 17 Mar., 1 Apr., or on 13 Apr. in 2008, and on 7 Mar., 29 Mar., 11 Apr., or on 26 Apr. in 2010. ${ }^{y_{L S D}}$ is least significant difference for the means calculated from the analysis of variance; NS is nonsignificant at $P>0.05$.

DW $( \pm \mathrm{SE})]$, fructose $(3.1 \% \pm 0.1 \%)$, and starch $(2.1 \% \pm 0.2 \%)$, with a lower concentration of sucrose $(1.2 \% \pm 0.1 \%)$, maltose $(0.4 \% \pm 0.1 \%)$, and sorbitol (less than $0.1 \%)$. The mean concentration of all the sugars measured was $8.7 \% \pm 0.2 \%$, and the mean concentration of the non-structural carbohydrates measured was $10.8 \% \pm 0.3 \%$. Soluble sugars accounted for more than three-fourths of the carbohydrates analyzed.

The mean concentration of non-structural carbohydrates was highest in the roots $(12.2 \% \pm 0.6 \% \mathrm{DW})$, intermediate in the leaves $(11.3 \% \pm 0.2 \%)$, and lowest in the crown $(9.0 \% \pm 0.3 \%)$. The concentration of sugars was highest in the leaves $(10.0 \% \pm 0.2 \%)$, intermediate in the roots $(8.9 \% \pm 0.4 \%)$, and lowest in the crown $(7.3 \% \pm 0.3 \%)$. There was a slightly different pattern with starch, which was highest in the roots $(3.4 \% \pm 0.3 \%)$, intermediate in the crown $(1.7 \% \pm 0.1 \%)$, and lowest in the leaves $(1.3 \% \pm 0.1 \%)$.

The effect of time of digging on the concentration of non-structural carbohydrates in the leaves was small (Table 2). For instance, the difference in the values of total nonstructural carbohydrates among the treatments was only $1.8 \% \mathrm{DW}$. The variation in the different components reflected the variation in the total pool. Time of digging had an intermediate effect on the crown and a greater effect on the roots with the concentration of total non-structural carbohydrates ranging from $7.5 \%$ to $11.0 \%$ and $8.4 \%$ to $16.8 \%$ in these plant parts (Table 2). This was mainly the result of changes in the concentration of fructose, maltose, and starch.

The total weight of non-structural carbohydrates/plant increased as harvesting was delayed with the roots (8.4-fold increase) more sensitive than the leaves (1.4-fold increase) or the crown (3.2-fold increase) (Table 1). There was also a change in the distribution of the carbohydrates with a decrease in the proportion stored in the leaves as harvesting was delayed and an increase in the proportion stored in the roots. These responses were reflected in the changes in the distribution of plant DW (Table 1). 
There were relationships between the concentration of non-structural carbohydrates in the crown and roots and the accumulation of chilling below $10{ }^{\circ} \mathrm{C}$ in the plants dug at different times (Fig. 1). There was no relationship between the concentration of carbohydrates in the leaves and the accumulation of chilling below $10^{\circ} \mathrm{C}$ and no relationship between the concentration of carbohydrate in any plant part and the accumulation of chilling below $7.2^{\circ} \mathrm{C}$. There were relationships between the concentration of nonstructural carbohydrates in the crown and roots and the number of days in the nursery in the plants dug at different times (Fig. 2). Some of the SES associated with the regression coefficients in these analyses were higher than those in the regressions with the accumulation of chilling.

Data were collected on the yield of the different treatments in 2008 when they were planted at Nambour (Table 3). Yields to the end of June, yields to the end of July, and relative total yield adjusted for the length of the growing season in the different treatments were highest in the plants dug on 17

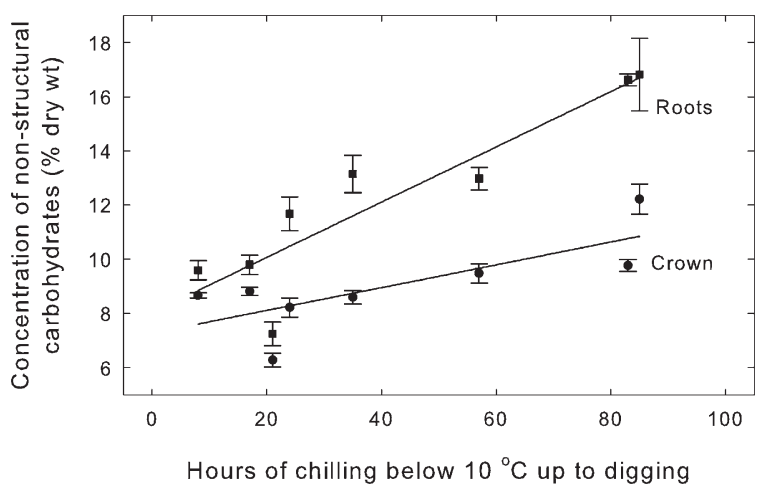

Fig. 1. Relationship between the concentration of non-structural carbohydrates and the accumulation of chilling below $10{ }^{\circ} \mathrm{C}$ in the 'Festival' strawberry plants dug from early March to late April at Stanthorpe in southern Queensland, Australia. Data are from four digging times over 2 years with four replicates per treatment $(\mathrm{N}=8)$. Bars show SEs of the means. Conc Crown $=7.3(\mathrm{SE}=0.7)+0.04(\mathrm{SE}=$ $0.01) \times$ hours of chilling $\left(R^{2}=0.51\right)$; and Conc Roots $=8.0(\mathrm{sE}=0.9)+0.10(\mathrm{sE}=0.02) \times$ hours of chilling $\left(R^{2}=0.80\right)$. Circles $=$ crowns; squares $=$ roots.

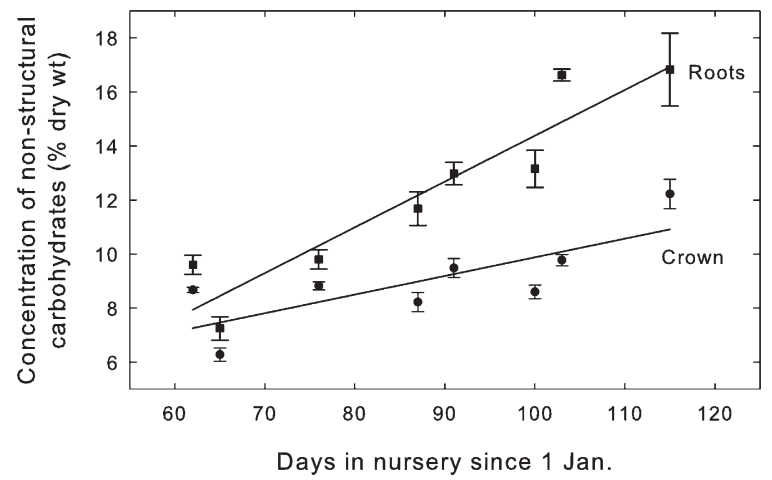

Fig. 2. Relationship between the concentration of non-structural carbohydrates and the number of days the 'Festival' strawberry plants spent in the nursery from 1 Jan. The plants were dug from early March to late April at Stanthorpe in southern Queensland, Australia. Data are from four digging times over 2 years with four replicates per treatment $(\mathrm{N}=8)$. Bars show SES of the means. Conc $_{\mathrm{Crown}}=3.0(\mathrm{SE}=$ $2.1)+0.07(\mathrm{sE}=0.02) \times$ days $\left(R^{2}=0.53\right) ;$ and Conc $_{\text {Roots }}=-2.6(\mathrm{SE}=2.2)+0.17(\mathrm{sE}=0.03) \times$ days $\left(R^{2}=\right.$ $0.86)$. Circles $=$ crowns; squares $=$ roots.

Table 3. The effect of time of digging on the yield of 'Festival' strawberry plants dug at Stanthorpe and grown at Nambour in southern Queensland, Australia, in 2008.

\begin{tabular}{lccc}
\hline Time of digging & $\begin{array}{r}\text { Yield to end of June } \\
(\mathrm{g} / \text { plant })^{z}\end{array}$ & $\begin{array}{r}\text { Yield to end of July } \\
(\mathrm{g} / \text { plant })^{\mathrm{z}}\end{array}$ & $\begin{array}{c}\text { Relative total yield } \\
(\mathrm{g} / \text { plant } / \text { week })^{\mathrm{z}}\end{array}$ \\
\hline 3 Mar. & 116 & 250 & 34.9 \\
17 Mar. & 175 & 382 & 42.0 \\
1 Apr. & 75 & 219 & 36.7 \\
13 Apr. & 57 & 181 & 30.7 \\
& & & 46
\end{tabular}

${ }^{\mathrm{z}}$ Data are the means of five replicates per treatment. Relative total yield was yield to mid-October divided by the length of the growing season that was 20 to 28 weeks in the different treatments.

${ }^{y}$ LSD is least significant difference for the means calculated from the analysis of variance.
Mar. with lower yields in the plants dug earlier or later.

The data in 2008 were used to explore the relationship between productivity and carbohydrate reserves in the transplants dug at different times. Plants dug from early March to mid-April had progressively greater weight of carbohydrates (as a result of increases in plant DW or concentration of carbohydrates), but these increasing reserves did not always correspond to increasing fruit yield. Plants dug on 17 Mar. had higher weights of non-structural carbohydrates (292 \pm $15 \mathrm{mg} /$ plant) than plants dug on 3 Mar. (224 \pm $30 \mathrm{mg} /$ plant) and higher yields (Table 3 ). Plants dug on 1 Apr. ( $408 \pm 37 \mathrm{mg} /$ plant) or on 13 Apr. (445 $\pm 17 \mathrm{mg} /$ plant) had higher reserves than the plants dug on 17 Mar. but lower yields. The higher reserves in the plants dug on 17 Mar. compared with those dug on 3 Mar. were mainly the result of higher plant DWs $(2.8 \pm 0.2 \mathrm{~g} /$ plant vs. $2.2 \pm 0.2 \mathrm{~g} /$ plant $)$ with the plants generally having similar concentrations of carbohydrates in the leaves, crown, and roots. The higher reserves in the plants dug on 1 and 13 Apr. compared with those dug on 17 Mar. were the result of both higher plant DWs $(3.6 \pm 0.3 \mathrm{~g} /$ plant and $3.6 \pm$ $0.1 \mathrm{~g} /$ plant vs. $2.8 \pm 0.2 \mathrm{~g} / \mathrm{plant})$ and higher concentrations of carbohydrates in the roots.

Nursery-growing environment. In 2008, mean average monthly maximum temperatures between January and April were similar at the two sites $\left(21.7^{\circ} \mathrm{C}\right.$ for Toolangi and $22.8^{\circ} \mathrm{C}$ for Stanthorpe), whereas the mean average monthly minimum temperature was $3{ }^{\circ} \mathrm{C}$ lower at Toolangi compared with conditions at Stanthorpe $\left(9.2^{\circ} \mathrm{C}\right.$ compared with $12.1^{\circ} \mathrm{C}$ ). In 2010 , mean average monthly maximum and minimum temperatures were 2 to $3{ }^{\circ} \mathrm{C}$ lower in the southern nursery (22.6 ${ }^{\circ} \mathrm{C}$ compared with $25.1^{\circ} \mathrm{C}$ and $11.2^{\circ} \mathrm{C}$ compared with $13.8{ }^{\circ} \mathrm{C}$ ). In 2008 , the differences in average maximum and minimum temperatures were $12.5^{\circ} \mathrm{C}$ at Toolangi compared with $10.7^{\circ} \mathrm{C}$ at Stanthorpe. In 2010 , the differences in average maximum and minimum temperatures were 10.1 and $11.3{ }^{\circ} \mathrm{C}$ at the two sites.

The plants from Stanthorpe were larger than those from Toolangi as a result of higher root DWs (Table 4). The plants from Stanthorpe also had a higher proportion of DW allocated to the roots and a lower proportion allocated to the crown. Allocation to the leaves was similar in the two nursery stocks.

The mean concentration of non-structural carbohydrates in the plants from the two nurseries was $10.7 \% \pm 0.3 \%$ with a similar make-up as found in the first experiment (mean concentration of $10.8 \% \pm 0.3 \%$ ). There was also a similar distribution of the sugars and starch in the different plant parts (data not presented).

The effect of nursery-growing environment on the concentration of non-structural carbohydrates in the plants was smaller than the effect of time of digging. The total concentration of non-structural carbohydrates was higher in the leaves and roots of plants from 
Table 4. The effect of nursery-growing area in Australia on plant dry weight and distribution [within brackets] and on the weight and distribution [within brackets] of non-structural carbohydrates in 'Festival' strawberry plants in 2008 and 2010 . $^{\text {z }}$

\begin{tabular}{|c|c|c|c|c|c|c|c|c|}
\hline \multirow[b]{2}{*}{ Nursery-growing area } & \multicolumn{4}{|c|}{ Dry wt (g/plant) or [dry wt distribution $(\%)]^{\mathrm{y}}$} & \multicolumn{4}{|c|}{$\begin{array}{l}\text { Wt of non-structural carbohydrates (mg/plant dry wt) } \\
\text { or [distribution }(\%)]^{\mathrm{y}}\end{array}$} \\
\hline & Leaves & Crown & Roots & Plant & Leaves & Crown & Roots & Plant \\
\hline Stanthorpe, Queensland & $2.1[53.4]$ & $0.7[16.9]$ & $1.2[29.7]$ & 4.0 & $260[54.2]$ & $61[13.0]$ & $157[32.8]$ & 478 \\
\hline Toolangi, Victoria & $1.8[55.1]$ & $0.7[21.2]$ & $0.8[23.7]$ & 3.3 & $175[54.0]$ & $63[19.5]$ & $87[26.5]$ & 325 \\
\hline $\operatorname{LSD}(P=0.05)^{\mathrm{x}}$ & NS [NS] & NS [1.1] & $0.2[2.6]$ & NS & $43[\mathrm{NS}]$ & NS [1.1] & $33[3.7]$ & 77 \\
\hline
\end{tabular}

${ }^{\mathrm{z}}$ Stanthorpe was classified as a warm-growing area and Toolangi as a cool-growing area.

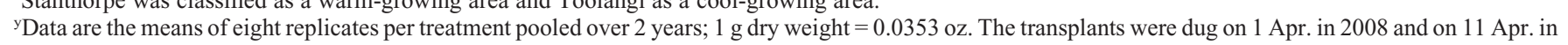
2010.

${ }^{\mathrm{x}}$ LSD is least significant difference for the means calculated from the analysis of variance; NS is nonsignificant at $P>0.05$.

Stanthorpe as a result of a higher concentration of sucrose and starch (leaves) or sucrose, maltose, and starch (roots) compared with the total concentration in the plants from Toolangi (Table 5). In contrast, the concentrations of non-structural carbohydrates in crowns of the two groups of plants were generally similar.

The stock from Stanthorpe had a greater weight of stored carbohydrates/plant than the stock from Toolangi as a result of greater reserves in the leaves and the roots (Table 4). This was associated with a higher allocation of total plant reserves to the roots in the stock from Stanthorpe compared with the allocation in the stock from Toolangi and a lower allocation to the crown. In other words, the stock from Stanthorpe had a greater weight of carbohydrates per plant than the stock from Toolangi mainly as a result of their larger roots.

Yields were collected from the plants from the two nursery-growing areas in 2008 when they were planted in Nambour. Early yield to the end of June or to the end of July and total yield until mid-October were not significantly $(P>0.05)$ different in the plants from the two nurseries (data not presented). The data in 2008 were used to explore the relationship between productivity and carbohydrate reserves in the transplants from the two nurseries. The transplants from Stanthorpe (408 $\pm 37 \mathrm{mg} / \mathrm{plant})$ had a greater weight of carbohydrates than the transplants from Toolangi (306 $\pm 18 \mathrm{mg} / \mathrm{plant})$, but the two groups of plants had similar yields. There was no relationship between yield and carbohydrate reserves in the two stocks.

\section{Discussion}

Time of digging had a strong effect on the accumulation of non-structural carbohydrates in the 'Festival' transplants growing in southern Queensland. Bare-rooted plants harvested in early March had lower reserves than plants harvested later. The plants from Toolangi also had lower reserves than the plants from Stanthorpe. Overall, reserves in the transplants only partially reflect their productivity in this environment.

Hicklenton and Reekie (2000) reviewed data relating quality and the concentration of non-structural carbohydrates in strawberry transplants, particularly plants that are stored at low temperatures before planting. Bringhurst et al. (1960) and Lieten (1997) suggested

Table 5. The effect of nursery-growing area in Australia on the concentration of non-structural carbohydrates in 'Festival' strawberry plants in 2008 and $2010 .^{\mathrm{z}}$

\begin{tabular}{|c|c|c|c|c|c|c|c|}
\hline \multirow[b]{2}{*}{ Nursery-growing area } & \multicolumn{7}{|c|}{ Concn of non-structural carbohydrates $(\% \text { dry wt })^{y}$} \\
\hline & Glucose & Fructose & Sucrose & Maltose & Total sugars & Starch & $\begin{array}{c}\text { Total } \\
\text { carbohydrates }\end{array}$ \\
\hline & & & & & Leaves & & \\
\hline Stanthorpe, Queensland & 4.4 & 3.6 & 2.2 & 0.3 & 10.5 & 1.6 & 12.1 \\
\hline Toolangi, Victoria & 4.3 & 3.4 & 1.0 & 0.2 & 8.9 & 0.9 & 9.8 \\
\hline $\operatorname{LSD}(P=0.05)^{\mathrm{x}}$ & NS & NS & 0.2 & NS & 0.5 & 0.2 & 0.5 \\
\hline & & & & & Crown & & \\
\hline Stanthorpe, Queensland & 3.3 & 2.8 & 0.7 & 0.3 & 7.2 & 1.9 & 9.1 \\
\hline Toolangi, Victoria & 3.1 & 3.3 & 0.7 & 0.5 & 7.6 & 1.6 & 9.2 \\
\hline $\operatorname{LSD}(P=0.05)$ & NS & 0.3 & NS & 0.1 & NS & 0.2 & NS \\
\hline & & & & & Roots & & \\
\hline Stanthorpe, Queensland & 4.5 & 3.4 & 0.6 & 0.9 & 9.5 & 3.6 & 13.1 \\
\hline Toolangi, Victoria & 4.2 & 3.6 & 0.3 & 0.5 & 8.7 & 2.5 & 11.2 \\
\hline $\operatorname{LSD}(P=0.05)$ & NS & NS & 0.2 & 0.1 & NS & 0.3 & 1.4 \\
\hline
\end{tabular}

${ }^{\mathrm{z}}$ Stanthorpe was classified as a warm-growing area and Toolangi as a cool-growing area.

${ }^{\mathrm{y}}$ Data are the means of eight replicates per treatment pooled over 2 years. The values for total sugars include values for the concentration of sorbitol; $1 \mathrm{~g}$ dry weight $=0.0353 \mathrm{oz}$. The transplants were dug on 1 Apr. in 2008 and on 11 Apr. in 2010.

${ }^{\mathrm{LSD}}$ is least significant difference for the means calculated from the analysis of variance; NS is nonsignificant at $P>0.05$.

a quality standard based on the concentration of starch or sucrose in the roots of the new transplants, but data collected by Hicklenton and Reekie did not support such general relationships. There was no threshold leaf or root starch or individual sugar concentration that reflected plant growth after storage. We were unable to demonstrate a critical concentration of carbohydrates in the plants for optimum production in southeastern Queensland.

Main non-structural carbohydrates in the strawberry plants. The main non-structural carbohydrates measured in the strawberry plants were glucose, fructose, and starch with lower concentrations of sucrose, maltose, and sorbitol. Soluble sugars were the dominant carbohydrates analyzed. Our results suggest that presenting data on reserves as starch or soluble sugars alone would underestimate the amount of non-structural carbohydrates in a plant. The inclusion of data for minor sugars such as inositol, xylose, and arabinose (Macías-Rodríguez et al., 2002) is not likely to result in significantly higher values of nonstructural carbohydrates.

Effect of time of digging on carbohydrate reserves. López et al. (2002) studied the reserves of 'Camarosa' and 'Pajaro' transplants growing at three nurseries located at different elevations $(10,284$, or $703 \mathrm{~m})$ in Spain over 3 years. There were strong correlations $\left(R^{2} \mathrm{~s}\right.$ of 0.87 and 0.64 ) between the concentration of starch in the crown and the accumulation of chilling below $7{ }^{\circ} \mathrm{C}$ until the end of December in the two cultivars. In our experiments, there were similar correlations between the concentration of non-structural carbohydrates and the time in the nursery or the accumulation of chilling in the nursery (Figs. 1 and 2). The weight of stored carbohydrates increased as digging was delayed. The crown and especially the root accumulated carbohydrates as digging was delayed. However, the leaves were still important and contributed on average approximately half of the plant's reserves.

The reserves of non-structural carbohydrates only partly reflected the productivity of the material dug at different times. Plants dug in early March had lower reserves than plants dug in mid-March and lower yields. However, further increases in reserves in plants dug in April were not reflected in higher productivity. Even when yields were adjusted for the shorter growing season, the plants planted in April still had lower relative yields than the plants planted in midMarch. Overall, the relationship between yield and carbohydrate reserves in this environment is unclear. Menzel and Smith (2011) showed that the optimum time for planting of 'Festival' in this area is mid-March with 
lower productivity from earlier or later plantings. The present study indicates that one of the reasons for the lower productivity of the plants planted in early March is that they have low reserves. This is mainly because these plants are smaller than the plants dug later.

Palha et al. (2002) found that there was a strong correlation between early yield and the concentration of non-structural carbohydrates in the roots before planting in strawberry plants grown in Portugal. The transplants were dug and stored at different times. Their work was slightly different from our studies in that they only measured the concentration of carbohydrates, not the weight of carbohydrates in the roots.

Effect of nursery-growing environment on carbohydrate reserves. The effect of nurserygrowing environment on reserves was smaller than the effect of time of digging. The plants from Stanthorpe (a warm-growing area) were larger than the plants from Toolangi (a coolgrowing area) and had a higher concentration and weight of carbohydrates in the leaves and roots.

López et al. (2002) found that strawberry transplants from a high-elevation nursery $(703 \mathrm{~m})$ generally had a higher concentration of starch in the crown than transplants from low- $(10 \mathrm{~m})$ or medium-elevation nurseries $(284 \mathrm{~m})$ in Spain. Differences in the concentration of soluble sugars among the three nurseries were not as great as those recorded for starch. The high-elevation nursery accumulated $\approx 1200$ to $2000 \mathrm{~h}$ of chilling below $7.0{ }^{\circ} \mathrm{C}$ over the 3 years of the experiment compared with 200 to $800 \mathrm{~h}$ of chilling in the low-elevation nursery. Conditions in these nurseries were much cooler than those recorded in Australia. Ruan et al. (2009) conducted similar work in Korea and found that the transplants grown at high elevation were approximately double the size of those grown at low elevation and generally had a greater concentration of sucrose, fructose, and glucose.

There was no clear relationship between productivity and carbohydrate reserves in the transplants from the two different nurseries. The plants from Stanthorpe had higher carbohydrate reserves than the plants from Toolangi but similar yields when grown at Nambour. Low temperatures can induce flower initiation in the nursery transplants (Durner et al., 1984; Stewart and Folta, 2010; Tanino and Wang, 2008). Durner et al. (1984) for instance showed that June-bearing cultivars produced 2.1 or 0.3 inflorescences/ plant when grown at day/night temperatures of $18 / 14$ or $22 / 18{ }^{\circ} \mathrm{C}$ under short days. No inflorescences were produced at higher temperatures. It is possible that better flowering in the stock from Toolangi counteracted their lower reserves of carbohydrates. The previous work showed that transplants from Stanthorpe had similar yields as transplants from Toolangi in 2 of 2 years (Menzel and Smith, 2011). The results reported here indicate that this occurs despite the plants from southern Queensland having greater reserves of stored carbohydrates.
Strawberry plants dug in mid-March had higher reserves and higher yields than plants dug in early March. In contrast, plants dug in April had higher reserves than those dug in mid-March but lower yields. Plants from Stanthorpe had higher reserves than plants from Toolangi but had similar yields, possibly because of poorer flowering. The reserves of carbohydrates in transplants only partially reflect potential productivity in this environment.

\section{Literature Cited}

Bringhurst, R.S., V. Voth, and D. van Hook. 1960. Relationship of root starch content and chilling history to performance of California strawberries. Proc. Amer. Soc. Hort. Sci. 75:373-381.

Bushway, L.J. and M.P. Pritts. 2002. Enhancing early spring microclimate to increase carbon resources and productivity in June-bearing strawberry. J. Amer. Soc. Hort. Sci. 127:415-422.

Da Silveira, A.J., F.F.F. Teles, and J.W. Stull. 1978. A rapid technique for total nonstructural carbohydrate determination of plant tissue. J. Agr. Food Chem. 26:770-772.

Durner, E.F., J.A. Barden, D.G. Himelrick, and E.B. Poling. 1984. Photoperiod and temperature effects on flower and runner development in day-neutral, June-bearing, and ever-bearing strawberries. J. Amer. Soc. Hort. Sci. 109:396400.

Gagnon, B., Y. Desjardin, and R. Bédard. 1990. Fruiting as a factor in accumulation of carbohydrates and nitrogen and in Fall cold hardening of day-neutral strawberry roots. J. Amer. Soc. Hort. Sci. 115:520-525.

Goldschmidt, E.E. and A. Golomb. 1982. The carbohydrate balance of alternate-bearing citrus trees and the significance of reserves for flowering and fruiting. J. Amer. Soc. Hort. Sci. 107:206208.

Hicklenton, P.R. and J. Reekie. 2000. Plant age, time of digging and carbohydrate content in relation to storage mortality and post storage vigor of strawberry plants. Acta Hort. 513:237-245.

Kirschbaum, D.S., D.J. Cantliffe, R.L. Darnell, E.B. Bish, and C.K. Chandler. 1998. Propagation site latitude influences initial carbohydrate concentration and partitioning, growth, and fruiting of 'Sweet Charlie' strawberry (Fragaria $\times$ ananassa Duch.) transplants grown in Florida. Proc. Florida State Hort. Soc. 111:93-96.

Kirschbaum, D.S., K.D. Larson, S.A. Weinbaum, and T.M. DeJong. 2010. Late-season nitrogen applications in high-latitude strawberry nurseries improve transplant production pattern in warm regions. Afr. J. Biotechnol. 9:1001-1007.

Lieten, F. 1997. Relation of digging date, chilling and root carbohydrate content to storability of strawberry plants. Acta Hort. 439:623-626.

Lieten, F., J.M. Kinet, and G. Bernier. 1995. Effect of prolonged cold storage on the production capacity of strawberry plants. Sci. Hort. 60:213219.

López, S., J.V. Maroto, A. San Bautista, B. Pascual, and J. Alagarda. 2002. Differences in carbohydrate content of waiting-bed strawberry plants during development in the nursery. Sci. Hort. 94:53-62.

Macías-Rodríguez, L., E. Quero, and M.G. López. 2002. Carbohydrate differences in strawberry crowns and fruit (Fragaria $\times$ ananassa) during plant development. J. Agr. Food Chem. 50:33173321.

MacKenzie, S.J., J.C. Mertely, and N.A. Peres. 2009. Curative and protectant activity of fungicides for control of crown rot of strawberry caused by Colletotrichum gloeosporiodes. Plant Dis. 93:815-820.

Menzel, C.M., T.S. Rasmussen, and D.R. Simpson. 1995. Carbohydrate reserves in lychee trees (Litchi chinensis Sonn.). J. Hort. Sci. 15:611-617.

Menzel, C.M. and L. Smith. 2011. Effect of time of planting, plant size and nursery-growing environment on the performance of 'Festival' strawberry in a subtropical environment. HortTechnology 21:56-66.

Menzel, C.M. and A. Toldi. 2010. An evaluation of containerized plants for strawberries growing in a subtropical environment. HortTechnology 20:786-793.

Nishizawa, T. 1994. Comparison of carbohydrate partitioning patterns between fruiting and deflorated June-bearing strawberry plants. J. Jpn. Soc. Hort. Sci. 62:795-800.

Nishizawa, T. and Y. Shishido. 1998. Changes in sugar and starch concentrations of forced Junebearing strawberry plants as influenced by fruiting. J. Amer. Soc. Hort. Sci. 123:52-55.

Nishizawa, T., Y. Shishido, M. Kudo, H. Kumakura, and H. Hamamoto. 1997. Petiole length, chlorophyll and carbohydrate levels, and photosynthetic rates of June-bearing strawberry plants as influenced by red-light irradiation during storage under cool conditions. Sci. Hort. 72: $25-33$.

Ohi, M., Y. Kawashima, S. Date, and Y. Yoshida. 1995. Seasonal changes in the soluble carbohydrate content of strawberry crown and roots. J. Jpn. Soc. Hort. Sci. 64:299-304.

Palha, M.G.S., D.R. Taylor, and A.A. Monteiro. 2002. The effect of digging date and chilling history on root carbohydrate content and cropping of 'Chandler' and 'Douglas' strawberries in Portugal. Acta Hort. 567:511-514.

Peres, N.A., J.F. Price, W.M. Stall, C.K. Chandler, S.M. Olson, T.G. Taylor, E.H. Simonne, and B.M. Santos. 2009. Strawberry production in Florida, p. 259-268. In: Olson, S.M. and E.H. Simonne (eds.). Vegetable production handbook for Florida 2009-2010. Vance Publishing, Lenexa, KS.

Pertuzé, R., M. Barrueto, V. Díaz, and M. Gambardella. 2006. Evaluation of strawberry nursery management techniques to improve quality of plants. Acta Hort. 708:245-248.

Ruan, J., C.S. Yoon, Y.R. Yeoung, K.D. Larson, and L. Ponce. 2009. Efficacy of highland production of strawberry transplants. Afr. J. Biotechnol. 8:1497-1501.

Santos, B.M., C.K. Chandler, M. Ramírez-Sánchez, and T.P. Salamé. 2009. Evaluation of strawberry cultivars in Florida. Intl. J. Fruit Sci. 9:419-424.

Schupp, J. and B. Hennion. 1997. The quality of strawberry plants in relation to carbohydrate reserves in roots. Acta Hort. 439:617-621.

Stewart, P.J. and K.M. Folta. 2010. A review of photoperiodic flowering research in strawberry (Fragaria spp.). Crit. Rev. Plant Sci. 29:1-13.

Tanino, K.T. and R.J. Wang. 2008. Modeling chilling requirement and diurnal temperature differences on flowering and yield performance in strawberry crown production. HortScience 43: 2060-2065.

Vock, N. 1997. Strawberry information kit. Department of Primary Industries, Nambour, Queensland, Australia.

Wang, S.Y. and M.J. Camp. 2000. Temperature after bloom affects plant growth and fruit quality of strawberry. Sci. Hort. 85:183-199.

Whitaker, V.M., T. Hasing, C.K. Chandler, A. Plotto, and E. Baldwin. 2011. Historical trends in strawberry fruit quality revealed by a trial of University of Florida cultivars and advanced selections. HortScience 46:553-557. 